\title{
SECOND DEMOGRAPHIC TRANSITION: ORIGINS AND CONCEPTS
}

\author{
${ }^{1}$ Natalia MEZENTSEVA, ${ }^{2}$ Natalia KONDRAS \\ 1,2Taras Shevchenko National University of Kyiv, Ukraine \\ 'provotarnat@ukr.net
}

\begin{abstract}
The second demographic transition is considered as the latest stage of demographic modernization, in economically developed countries it took place in the early 1970s, when the first signs of fundamental changes in fertility and family models occurred in cities of USA, Canada, Denmark, Sweden and Finland. The main criterion of initiated changes was fertility decrease in women under 20 years and raising age of the marriage. The second demographic transition is the result of widespread individualisticoriented system of values in modern society and a corresponding change in the rules of the demographic behavior of individuals. Its main features are increasing number of unregistered marriages; increase in the average age of a registered marriage, the average age of first birth and the average age of motherhood in general; increase in the share of illegitimate births; reducing the proportion of fertility in the youngest age group of mothers and increasing the share of older age groups of mothers; raising divorce ratio. The concept of the second demographic transition is widely investigated under significant demographic changes of recent decades in developed countries. Current demographic processes in Central and Eastern Europe confirm the features that are characterized the second demographic transition. Ukraine as Central and Eastern Europe also has a number of features of the second demographic transition, which is geographically differentiated. The article provides an overview of international research concepts of demographic processes and analysis of contemporary features of demographic processes in Ukraine in the context of the second demographic transition.
\end{abstract}

Key words: demographic transition, birth rate, marriage, fertility, demographic processes, Ukraine.

UDC: 911.3

\section{ДРУГИЙ ДЕМОГРАФІЧНИЙ ПЕРЕХІД: ВИТОКИ ТА КОНЦЕПЦІї}

\author{
${ }^{1}$ Наталія МЕЗЕНЦЕВА, ${ }^{2}$ Наталія КОНДРАСЬ \\ 1,2Київський національний університет імені Тараса Шевченка, Україна \\ 'provotarnat@ukr.net
}

Анотація: Другий демографічний перехід вважається найновішим етапом демографічної модернізації, в який економічно розвинуті країни світу вступили на початку 70-х років XX ст., коли з'явилися перші ознаки кардинальних змін моделі сім'ї і народжуваності в містах США, Канади, Данії, Швеції та Фінляндії. В якості критерію розпочатих змін стало зниження народжуваності у жінок до 20 років та підвищення віку вступу в шлюб. Другий демографічний перехід $\epsilon$ результатом широко розповсюдженої індивідуалістично орієнтованої системи цінностей в сучасному суспільстві та відповідної зміни норм демографічної поведінки індивідів. Основними його рисами визначені: зростання кількості незареєстрованих шлюбів; збільшення середнього віку вступу в зареєстрований шлюб, середнього віку народження першої дитини та середнього віку материнства в цілому; зростання частки позашлюбних народжень; зниження частки у показниках народжуваності наймолодшої вікової групи матерів та підвищення частки старших вікових груп матерів; підвищення рівня розлучуваності. Концепція другого демографічного переходу $\epsilon$ широко досліджуваною в рамках суттєвих демографічних змін останніх десятиліть у економічно розвинутих країнах світу. Сучасні демографічні процеси в країнах Центральної та Східної Європи підтверджують риси, що притаманні другому демографічному переходу. Україна як держава Центрально-Східної Європи також має ряд ознак другого демографічного переходу, які $\epsilon$ територіально диференційованими. В статті представлено огляд зарубіжних концепцій дослідження демографічних процесів та результати аналізу сучасних рис демографічних процесів в Україні в контексті другого демографічного переходу.

Ключові слова: демографічний перехід, народжуваність, шлюб, фертильність, демографічні процеси, Україна.

удк: 911.3

Постановка проблеми. Сукупність змін демографічної поведінки населення останніх 35-40 років в світі визначають терміном другого демографічного переходу. Якщо перший демографічний перехід супроводжувався модернізацією суспільства на етапі розширення можливостей для задоволення матеріальних потреб, то для другого демографічного переходу характерним $є$ зосередження життєвих пріоритетів людей на особистому розвитку та індивідуальному стилі життя. Через нові погляди на сім'ю, народження дітей, взаємовідносини 3 партнерами це відображається

(C) Н. Мезенцева, Н. Кондрась в показниках шлюбності та розлучень, віку вступу в шлюб та віку народження першої дитини, коефіцієнтах народжуваності, фертильності та має різний ступінь появу за регіонами світу, країнами, урбанізованими територіями і сільською місцевістю.

Ознаки другого демографічного переходу характерні i для України. Однак концепція другого демографічного переходу практично відсутня у суспільно-географічних дослідженнях демографічних процесів в регіонах України. Саме тому виникає потреба в огляді наукової дискусії провідних вчених світу щодо витоків, сутності концепції другого демографічного переходу, визначення його індикаторів 3 метою проведення 
суспільно-географічних досліджень сучасних демографічних змін та процесів в Україні та їі регіонах.

Формулювання цілей статті. Метою написання даної роботи є огляд сучасних зарубіжних концепцій дослідження демографічних процесів та виявлення сучасних рис демографічних процесів в Україні в контексті другого демографічного переходу.

Виклад основного матеріалу. Витоки концепції демографічного переходу беруть початок 320 -х років ХХ століття. У 1929 році у праці американського демографа У.Томпсона «Населення» вперше було описано зміни (переходи) в народжуваності i смертності в промислово розвинених країнах протягом останніх 200 років. Із аналізу цих змін автором була створена модель, яка в загальному відображала перехід суспільства від традиційного режиму відтворення населення, що характеризується високим рівнем народжуваності та смертності, до іншого режиму, де обидва показники є значно нижчими. У своїй роботі Томпсон виділив 3 групи країн [18]:

1. група A, яка характеризується достатньо низьким рівнем смертності та рівнем народжуваності, який швидко скорочується, що приводить до зниження приросту, а згодом і до природного скорочення населення (Західноєвропейські країни);

2. група В, яка складається 3 країн в яких відбувається швидке та різке зниження смертності і поступове зниження народжуванності. В результаті спостерігається зростання чисельності населення до тих пір поки тривале зниження народжуваності не приведе до стабілізації, а згодом скорочення чисельності (країни Східної та Південної Свропи);

3. група С, яка характеризується високими рівнями обох показників. Ця група отримала назву Мальтузіанська за ім'ям Томаса Мальтуса, який висунув теорію згідно якої неконтрольований ріст народонаселення має привести до голоду на Землі (до групи віднесено 70\% населення Землі).

У 1934 році французький вчений А.Ландрі опублікував книгу «Демографічна революція», завдяки якій в широкий обіг було введено поняття «демографічної революції» та відображено динаміку зміни «демографічних типів» - переходу від «примітивного» через «перехідний» до «сучасного» [1]. Класифікація А.Ландрі була дещо схожа із розробками У. Томпсона. Він також висунув ідею, що передбачала поширення Західноєвропейського режиму відтворення населення для всього світу вцілому, проте країни, що вступили на стадію переходу пізніше, повинні були б мати вищі темпи змін [2]. Ще одним важливим доробком А. Ландрі було те, що він заклав підвалини для розвитку ідей індивідуалізму, як причин, що визначали рівень зниження відтворення населення.

Вперше в науковий обіг власне термін «демографічний перехід» був введений американським демографом Ф. Ноунстайном у роботі виконаній спільно із доктором Р. Стікс «Контрольована фертильність» (1940р.), повне визначення поняття було представлено у доповіді
«Економічні проблеми змін чисельності населення» на 8 Міжнародній конференції 3 економіки сільського господарства у 1953 році [15]. На основі безпосередніх спостережень та попередніх праць по теорії демографічного переходу Ноунстайн прийшов до висновку, що саме зміна установок, а не просто винахід сучасних засобів контрацепції, призвели до зниження народжуваності [3]. Ці висновки дозволили надати чітке формулювання поняття «демографічного переходу», як переходу від суспільства традиційного аграрного типу до міського індустріального.

Ф.Ноунстайн передбачив, що взаємодія між соціальними змінами та демографічними тенденціями (демографічний перехід) несе в собі потенціал дуже швидкого росту населення в менш розвинутих країнах. Соціально-економічний прогрес приведе до загального зниження смертності задовго до того як розпочнеться зниження народжуваності, що й призведе до швидкого росту чисельності населення. За Ноунстайном деякі бідні регіони світу є настільки густо населеними, що демографічні тенденції стануть на шляху подальшого їх прогресу [15].

А.Ландрі та Ф.Ноунстайн $є$ представниками раціональної концепції демографічного переходу, що передбачає гомеостатичне регулювання відтворення населення відповідно до якого рівень народжуваності в кінцевому підсумку визначений рівнем смертності. Індустріалізація знижує смертність населення та створює передумови для зниження народжуваності, свідомого раціонального вибору особистості щодо зменшення кількості дітей. Прихильники раціональної концепції протиставляють свідомому обмеженню кількості дітей у сім’ї в урбанізованому індустріальному суспільстві ірраціональну репродуктивну поведінку населення у аграрному суспільстві.

Інша концепція демографічного переходу грунтується на твердженні про відносну незалежність еволюції народжуваності від динаміки смертності. Так як народжуваність і смертність визначаються соціально-економічними умовами, перебудова типу народжуваності залежить не стільки від зниження смертності, скільки від глибинних сутнісних соціально-економічних перетворень, що формують індустріальне суспільство [16].

Вирізняють чотири фази демографічного переходу. В першій фазі, яку до середини XX ст. завершили промислово розвинені країни, зниження коефіцієнта смертності випереджає зниження коефіцієнта народжуваності, завдяки чому коефіцієнт природного приросту населення зростає до найвищого значення. У другій фазі коефіцієнт смертності знижується далі та досягає найменшого значення, але коефіцієнт народжуваності знижується ще швидше, i приріст населення поступово сповільнюється. Для третьої фази характерне підвищення коефіцієнта смертності, обумовлене демографічним старінням населення 3 одночасним сповільненням зниження народжуваності. Врештірешт коефіцієнт народжуваності наближається до рівня простого відтворення населення, а коефіцієнт 
смертності залишається нижчим від цього рівня, оскільки вікова структура ще не стабілізована і має збільшену частку вікових груп із низькою смертністю. В четвертій фазі коефіцієнт смертності підвищується, зближуючись із коефіцієнтом народжуваності, а процес демографічної стабілізації закінчується.

Як спроба дати теоретичне пояснення сучасної $\mathrm{i}$ майбутньої демографічної ситуації, виникла гіпотеза «другого демографічного переходу». Подібні ідеї висуваються також і в рамках гіпотези про п'яту фазу демографічного переходу. Автори концепції другого демографічного переходу Р. Лестег і Д. Ван де Каа доводять, що сучасна демографічна ситуація і головна iii особливість - зниження народжуваності нижче рівня, що забезпечує просте відтворення населення - обумовлені принципово іншими причинами в порівнянні зі зниженням народжуваності під час першого демографічного переходу (sub-replacement fertility) [20].

В основу концепції другого демографічного переходу покладені ідеї 80-х років XX ст. Зокрема Д. Ван де Каа визначив, що з середини 1970-х років Європа вступила в нову стадію іiі демографічної iсторії. Він припускає, що демографічний перехід XIX та половини XX століть необхідно розглядати як перший перехід. «Несподівані», «заплутані» зміни в демографічній ситуації з середини 1960-х років відзначили початок другого демографічного переходу. До цього часу вже закінчився післявоєнний сплеск народжуваності й утвердилася довготривала тенденція до зниження народжуваності [19].

Р. Лестег стверджує, що ранні ознаки другого демографічного переходу з'явилися в 1950-х роках: кількість розлучень зросла, особливо в Сполучених Штатах та Скандинавії, а відхід від довічного зобов'язання в шлюбові виправдався логікою, що «хороше розлучення краще, ніж поганий шлюб». 3 другої половини 1960-х років і далі, народжуваність почала знижуватись [14].

Можна вести мову і про інші ознаки другого демографічного переходу. Це стосується віку вступу в перший шлюб, поширення дошлюбного співжиття, тенденцій щодо розлучень, які рідше ведуть до повторного шлюбу, а частіше до спільного проживання. До 1980-х років від Скандинавії до інших частин Західної Європи поширилось дітонародження в спільно проживаючих парах. У Франції та Великобританії понад 40\% всіх дітонароджень нині відбуваються поза шлюбом, тоді як у 1960 році цей показник для обох країн був близько $6 \%$ [14].

Серед авторів концепції другого демографічного переходу не існує єдиної думки щодо його просторової універсальності. Відсутня також і єдина думка про причини другого демографічного переходу. Найпоширенішою $є$ точка зору, що він $є$ наслідком широко розповсюдженої індивідуалістично орієнтованої системи цінностей в сучасному суспільстві та відповідної зміни норм демографічної поведінки індивідів. Нині в суспільстві відбувається суттєве збільшення ступеня свободи як у виборі індивідуальних цілей, так і засобів їх досягнення. Після того як другий демографічний перехід з'являється як одна 3 характеристик капіталістичної економіки та культура, яка визнає першість індивідуальної автономії, відбувається процес розвитку потреб вищого рівня, насамперед, такої як самореалізація [14].

Д. Ван де Каа розглядає другий демографічний перехід як результат руху суспільної свідомості від консерватизму до прогресивності. При цьому прогресивність розуміється як толерантність i готовність сприйняття нових цінностей i моделей поведінки. На думку Д.Коулмана другий демографічний перехід пов'язаний 3 більш широким набором «постматеріалістичних» i «постмодерністських» соціальних, економічних та інституційних змін, які розгортаються в розвинених країнах світу протягом останніх тридцяти років $[12,9]$. Демографічні зміни в шестидесятих роках $\epsilon$ результатом зміни поведінки як чоловіків i жінок окремо, так і безпосередньо пар. В області шлюбності i народжуваності доступність нових, високоефективних засобів контрацепції, часто супроводжувана збільшеними можливостями здійснення аборту та стерилізації, послужила певним каталізатором.

Д. Ван де Каа виділяє чотири основні риси другого демографічного переходу [20]:

- перехід від «золотого століття» шлюбу до його заходу, тобто широке поширення юридично неоформлених форм спільного життя і альтернативних форм сім'ї;

- перехід від дітоцентриської моделі сім'ї до індивідуалістично орієнтованої «зрілої» пари партнерів з однією дитиною;

- перехід від превентивної контрацепції, призначеної для запобігання народжень ранніх дітей, до свідомого планування народження кожної дитини;

- перехід від уніфікованої моделі до плюралістичної моделі родини.

Таким чином, другий демографічний перехід виявляє набір подій, які безпосередньо пов'язані 3 «атомізацією» і «індивідуалізацією» суспільства, в результаті підйому з «рефлексивного Я» виникнення «суспільства дружби» i зростаючого значення «слабких зв'язків» [10,11].

Важливими наслідками другого демографічного переходу, що впливають на народжуваність, $є$ [23]:

- абсолютне і відносне зростання кількості незареєстрованих шлюбів, більш-менш тривалих дошлюбних спілок, сепарацій (роздільного проживання партнерів) при одночасному швидкому зменшенні частки поспішних, вимушених шлюбів, стимульованих вагітністю в юному віці;

- зростання середнього віку вступу в зареєстрований шлюб, середнього віку народження першої дитини і середнього віку материнства в цілому;

- зростання частки позашлюбних народжень при збільшенні середнього віку матері при народженні позашлюбної дитини; 
- зменшення ексцесу (гостровершинності) вікового розподілу народжень, поступове переміщення модального віку 3 вікової групи 20-24 роки у вікову групу 25-29 років (а в деяких країнах навіть у вікову групу 30-34 роки), різке зниження частки у показниках народжуваності наймолодшої вікової групи матерів (15-20 років) та підвищення частки старших вікових груп матерів (старше 30 років), в результаті чого розподіл народжень стає більш рівномірним за віковою шкалою. Отримання освіти i пошук першої роботи в економічно розвинених країнах, як правило, «не перевантажується проблемами, пов'язаними 3 виконанням материнських функцій. 3 цієї причини низький внесок молодих жінок (до 25 років і особливо до 20 років) в загальний рівень народжуваності компенсується підвищенням вкладу жінок середніх і старших вікових груп.

- підвищення рівня розлучуваності, поява нетрадиційних форм співжиття, таких як проживання «роздільно-разом», «спільне житло» («share apartment»), поширення «step-family» (сімей, що сформувались після другого одруження одного із членів пари, в якого є діти) [9].

Поняття другого демографічного переходу пов'язують 3 реурбанізацією та джентрифікацією. Дослідження виконане в рамках П'ятої Програми Європейського Союзу «Реурбанізація в умовах демографічних змін» розкриває цей тісний взаємозв'язок. Більшість соціальних груп, які $€$ рушіями реурбанізації, випливають 3 демографічних змін, що $\epsilon$ інкапсульованими 3 другого демографічного переходу: старіння, низька фертильність, відкладений шлюб та дітонародження, зниження рівня шлюбності та зростання коефіцієнту розлучуваності, зростання чисельності дітей народжених поза шлюбом, зростаюча чисельність «нетрадиційних» або непостійних родин [4]. Міські моделі сім'ї в постмодерністській структурі родини є зростаючим доказом соціо-просторових змін i пов'язані із трендами другого демографічного переходу [7].

Р. Лестег у праці «Розгорнута історія другого демографічного переходу» зазначає, що концепція піддавалась досить жорсткій критиці. По-перше, стверджувалося, що другий демографічний перехід $\epsilon$ лише продовженням першого переходу [5]. По-друге, за словами Д. Коулмана, це не є «другий перехід», а всього лише «вторинна ознака» першого демографічного переходу. Другий демографічний перехід буде навіть не демографічний по своїй суті, а лише «частковий результат вибору стилю життя» [6]. По-трете, більш поширеним аргументом, особливо в 1990-і роки, було те, що другий демографічний перехід є прототипом для Західної Свропи (також для Канади і Австралії), особливістю, яка не буде поширюватися в США або в Південну, Центральну та Східну Європу, не кажучи вже про Азію. Демографічні зміни в цих частинах Свропи можуть бути спричинені економічними потрясіннями, пов'язаними 3 переходом від комуністичної командно-адміністративної до ринкової економіки, без врахування культурних зрушень. По-четверте, йшлося по те, що теорія другого демографічного переходу переоцінить зв'язок між змінами в сімейних відносинах (особливо співжиття) і поширеністю sub-replacement fertility. По-п’яте, концепція другого демографічного переходу не може пояснити велику різноманітність рівнів народжуваності [14].

Демографічні тенденції у Центральній $i$ Східній Європі в контексті другого демографічного переходу. У Центральній і Східній Європі у 1990-х роках з'явилися такі нові демографічні тенденції: вік вступу в перший шлюб, який залишався досить юним протягом попередньої епохи, почав зростати; поширилося дошлюбне спільне проживання; зросла кількість народжених позашлюбних дітей; збільшилася чисельність пізніх шлюбів; знизився рівень фертильності нижче 1,5 дитини i навіть нижче 1,3. Був введений новий термін - «фертильність нижча нижчої» (lowest-low fertility) [13]. Це призвело до різкого скорочення показників народжуваності, періодичні заходи для стимулювання якої були недієвими. Окремі дослідники даного регіону припускали, що це може бути початком другого демографічного переходу. Проте скептично налаштовані щодо концепції другого демографічного переходу демографи вважали, що відкладений шлюб і відстрочка народження дітей були виключно наслідками економічної кризи. Економічна комісія $\mathrm{OOH}$ спочатку приймала саме цю точку зору, зважаючи на те, що соціально-економічні трансформації в постсоціалістичних країнах привели до появи цілого ряду негараздів: скасування гарантованого довічного працевлаштування, різкого падіння рівня життя, скорочення державної підтримки для сімей, приватизації в житловому секторі, зростання бідності.

Ряд вчених, насамперед, з Чехії [24,17], Росії [21, 22] вважали, що, незважаючи на економічну кризу, другий демографічний перехід може бути в процесі становлення в країнах Центральної та Східної Європи. В кінці 1990-х років економіка окремих країн вийшла $з$ кризового стану, що супроводжувалось зростанням доходів на душу населення. При цьому не відбулося повернення демографічної поведінки до моделей ранього шлюбу, підвищення народжуваності. Навпаки спостерігалось стійке зростання позашлюбної народжуваності.

Отже, економічна криза дестабілізувала демографічний режим країн Східної та Центральної Європи, але перші ознаки другого демографічного переходу були характерні для них ще до 1990 року. Нині демографічні процеси в країнах Центральної та Східної Європи підтверджують притаманні другому демографічному переходу риси.

Сучасні риси демографічних процесів в Україні в контексті другого демографічного переходу. Ознаки депопуляції населення України почали проявлятися 3 кінця 1970-х років і були характерні для сільської місцевості, де коефіцієнт природного приросту населення став від'ємним. Негативні тенденції відтворення населення як у містах, так 
і в сільській місцевості поглибилися у результаті економічної кризи 1990-х років. Розглянемо окремі складові демографічних процесів в Україні в контексті другого демографічного переходу за період з 1989 року, коли було проведено черговий перепис населення, до 2014 року.

1. Для України було характерне скорочення рівня народжуваності у період 1991-2001 рр., коли коефіцієнт народжуваності зменшився в 1,6 разів і досяг у 2001 році свого мінімального значення 7,7 осіб на тис. 32001 по 2008 рік коефіцієнт народжуваності зростав, а з 2008 по 2014 рік фактично стабілізувався на рівні 11 осіб на тис. Тобто для України в цілому не характерна однозначно негативна динаміка рівня народжуваності.

2. Коефіцієнт фертильності в Україні скорочувався 3 1,7 у 1991 році до 1,1 у 2000-2002 pp., а далі поступово зростав, досягши у 20112014 роках позначки 1,5. Отже, для України також не характерна однозначна негативна динаміка коефіцієнта фертильності. Його найнижчі значення, як і коефіцієнта народжуваності, на початку 2000-х років були значною мірою зумовлені затяжною багатоаспектною соціально-економічною кризою в суспільстві.

3. В Україні постійно зростає частка сімей, що мають одну дитину. Якщо у 1989 році частка таких сімей складала 52,1\%, то у 2000 р. - 60,3\%, а у 2008 р. - 70,9\%. Водночас постійно знижується частка сімей, що мають 3 і більше дітей. Так у 1989 році їх частка дорівнювала $6,4 \%$, а у 2008 р. зменшилась в 1,7 разів до $3,7 \%$.

4. Середній вік жінки при народженні дитини в Україні має стабільну тенденцію до підвищення. Так, у 2000 році він складав 24,5 роки, у 2005 р. - 25,4 років, у 2010 р. - 26,1 років.

5. Частка дітей, які народжені жінками віком до 20 років постійно знижується. Якщо у 1991 році частка таких дітей складала 18,3\%, то у 2013 році вона знизилась втричі до $6,1 \%$. Водночас частка дітей народжених матерями віком понад 40 років має стабільну тенденцію до збільшення і зросла з 1991 до 2013 року вдвічі з $0,9 \%$ до 1,8\%.

6. Коефіцієнт шлюбності в Україні не характеризується однозначною тенденцією його зміни. Впродовж $1990-х$ років він знизився в 1,7 разів з показника 9,5 у 1989 р. до мінімального значення 5,6 у 2000 р., а далі поступово зростав. У 2010-2014 рр. коефіцієнт шлюбності стабілізувався на рівні 6,7.

7. В Україні постійно підвищується середній вік вступу в шлюб та середній вік при реєстрації першого шлюбу. Зокрема, середній вік при реєстрації першого шлюбу збільшився для жінок та чоловіків 322,5 і 25,3 років у 2000 р. до 24,5 і 27 років у 2012 р.

8. Широкого поширення в Україні набув громадський шлюб, як юридично неоформлена форма спільного проживання.

9. Питома вага дітей народжених у матерів, які не перебували у зареєстрованому шлюбі, в Україні постійно зростає. Якщо у 1991 р. вона складала 11,9\%, то у 2013 р. зросла майже вдвічі до 22,1\%.

10. В Україні щороку здійснюється значна кількість абортів. Незважаючи на те, що їх кількість стабільно зменшується (3 957 тис. у 1991 р. до 176 тис. у 2010 р.), показники кількості абортів на 100 пологів та на 1000 жінок фертильного віку залишаються значними в негативному сенсі - 35,6 та 15,1.

11. Прояв різних ознак другого демографічного переходу в Україні характеризується значною територіальною диференціацією, викликаною різними чинниками (рівнем соціально-економічного розвитку, проживанням в містах чи сільській місцевості, статусом міста, рівнем релігійності населення та ін.).

Висновки. Концепція другого демографічного переходу стала «мейнстрімом» Європейської Асоціації 3 вивчення проблем народонаселення (European Association for Population Studies). У 2001 році було проведено першу конференцію (EURESCO-conference), яка мала назву «Другий демографічний перехід. Сім'я і зміни фертильності у сучасному суспільстві: дослідження та пояснення сучасного розвитку», та створено робочу групу, що займається дослідженням демографічних процесів в рамках другого демографічного переходу. В результаті проведених досліджень, були зроблені висновки про те, що: Скандинавські країни перебувають на найвищому рівні другого демографічного переходу; Західна та Південна Європа мають головні ознаки демографічних змін, що характерні для другого демографічного переходу; Центральна та Східна Європа мають значний прояв таких ознак. Україна як держава Центрально-Східної Свропи має прояви окремих ознак другого демографічного переходу, які характеризуються значною територіальною диференціацією. Це потребує грунтовного просторового аналізу тенденцій різноманітних складових демографічних процесів в регіонах України.

\section{References:}

1. 140 let so dnâ roždeniâ Adol'fa Landri [140 anniversary from Adolphe Landry Birth Day] Bûlleten' Institutu demografii Nacional'nogo issledovatel'skogo universiteta "Vysšaâ škola èkonomiki” Demoskop Weekly \# 611 - 612 [Bulletin of National Demography Institute, Research University “Higher School of Economics"]. Access Mode: http:// demoscope.ru/weekly/2014/0611/nauka01.php (in Russian).

2. Adol'f Landri. Demografičeskaâ revolûciâ [Adolphe Landry. Demographic Revolution] Bûlleten' Institutu demografii Nacional’nogo issledovatel'skogo universiteta “Vysšaâ škola èkonomiki” Demoskop Weekly \# 611 - 612 [Bulletin of National Institute of demography Research University "Higher School of Economics"]. Access Mode: http://demoscope.ru/weekly/2014/0611/nauka02.php (in Russian). 
3. Ansley J. Coale, Frank W. Notestein, 1902-1983. Population Index, Vol. 49, No. 1 (Spring, 1983), pp. 3-12.

4. Bongaarts J. The end of the fertility transition in the developed world. Population and Development Review, 2002, Vol. 28, pp. 419-443.

5. Cliquet R. The Second Demographic Transition: Fact or Fiction? Strasbourg, France: Council of Europe, Council of Europe Population Studies, 1991, 23.

6. Coleman D. Why we don't have to believe without doubting in the "Second Demo graphic Transition"? Some agnostic comments. Vienna Yearbook of Population Research, 2004, pp. 11-24.

7. Delphy C, Leonard D. Familiar exploitation: a new analysis of marriage of contemporary society. Cambridge Center, Cambridge, MA, 1992.

8. European Association for Population Studies. The second demographic transition in Europe (completed). Access Mode: http://www.eaps.nl/scientific-activities/working-groups/second-demographic-transition-europe-completed.

9. Frey W. H., Kobrin F. E. Changing families and changing mobility: Their impact on the central city. Demography, 1982, Vol. 19, pp. 261-277.

10. Giddens A. Modernity and Self-Identity: Self and Society in the Late Modern Age. Stanford, CA: Stanford University Press, 1991.

11. Granovetter M. S. The strength of weak ties. American Journal of Sociology, 1973, Vol. 78, 1360-1380.

12. Inglehart R. Modernisation and Postmodernisation: Cultural, Economic and Political Change in 43 Societies. Princeton University Press, Princeton, NJ, 1997.

13. Kohler H-P., Billari F. C., Ortega J. A. The emergence of lowest-low fertility in Europe during the 1990s. Population and Development Review, 2002, Vol. 28(4), pp. 641-680.

14. Lesthaeghe R. The Unfolding Story of the Second Demographic Transition, Population and Development Review, 2010, Vol. 36, No. 2, pp. 211-251

15. Notestein F. W. Economic problems of population change. Proceedings of the Eighth International Conference of Agricultural Economists. London: Oxford University Press, 1953, pp. 13-31

16. Pribitkova İ. M. Osnovi demografiï: posibnik dlâ studentiv gumanitarnih ta suspil'nih fakul'tetìv viŝih navčal'nih zakladìv [Basics of demography: Textbook for students of humanities and social faculties of higher educational institutions] Kyiv. 1995, 256 p. (in Ukrainian).

17. Sobotka T. Ten years of rapid fertility changes in European post-Communist countries? Evidence and interpretation. Groningen Population Research Center Working Papers, no. 2002.

18. Thompson W. Encyclopedia of Population Macmillan Reference. 2003. pp. 939-40. Access Mode: http://www. faculty.fairfield.edu/faculty/hodgson/Courses/so184/popdocs/EofPThompson.pdf

19. Van de Kaa D. J. The idea of a second demographic transition in industrialized coun tries. Papers of 6th Welfare Policy Seminar, 2002. Access mode: http://www.ipss.go.jp/webj-ad/webjournal.files/population/2003_4/kaa. pdf

20. Van de Kaa D. J. Second Demographic Transition: concepts, dimensions, new evidence. Bad Herrenalb, 23-28 June 2001. Access mode: http://www.demogr.mpg.de/papers/workshops/010623_paper04.pdf

21. Zakharov S. Fertility trends in Russia and the European new independent states: Crisis or turning point? Expert Group Meeting on Below-Replacement Fertility, ESA/ P/WP.140, 4-6 November 1997, New York: United Nations Population Division.

22. Zakharov S., Ivanova E. Fertility decline and recent changes in Russia? On the threshold of the second demographic transition. In J. DaVanzo (ed.), Russia's Demographic Crisis. Santa Monica: RAND, 1996, pp. 36-82

23.Zaharov S. Vtoroj demografičeskij perehod i izmenenie vozrastnoj modeli roždaemosti [The second demographic transition and changes in the age patterns of fertility] Bûlleten' Institutu demografii Nacional'nogo issledovatel'skogo universiteta "Vysšaâ škola èkonomiki" Demoskop Weekly \# 611 - 612 [Bulletin of National Institute of demography Research University "Higher School of Economics"]. Access mode: http://demoscope.ru/weekly/2012/0495/tema05. php (in Russian).

24. Zeman K., Sobotka T., Kantorova V. Halfway between socialist greenhouse and postmodern plurality: Life course transitions of young Czech women, paper presented at the European Science Foundation Seminar on the Second Demographic Transition, Bad Herrenalb, 23-28 June 2001. 